\title{
Marinobacterium nitratireducens sp. nov. and Marinobacterium sediminicola sp. nov., isolated from marine sediment
}

Correspondence
Xue-Wei Xu
xuxw@sio.org.cn
Min Wu
wumin@zju.edu.cn

The genus Marinobacterium was proposed by González et al. (1997) with the description of a single species, Marinobacterium georgiense. Subsequently, Oceanospirillum jannaschii and Pseudomonas stanieri were reclassified into the genus as Marinobacterium jannaschii and Marinobacterium stanieri (Satomi et al., 2002; Euzéby \& Tindall, 2004). Three further species in the genus, Marinobacterium halophilum (Chang et al., 2007), Marinobacterium litorale (Kim et al., 2007) and Marinobacterium rhizophilum (Kim et al., 2008), were described recently. Here we present a polyphasic study describing two novel Marinobacterium strains isolated from the sediment of the East China Sea.

The GenBank/EMBL/DDBJ accession numbers for the 16S rRNA gene sequences of strains $\mathrm{CN}_{4}{ }^{\top}$ and $\mathrm{CN}^{\mathrm{T}} 7^{\top}$ are EU573965 and EU573966, respectively.

A supplementary table showing the major fatty acids of strains $\mathrm{CN} 44^{\top}$ and $\mathrm{CN} 47^{\top}$ is available with the online version of this paper.
Strains $\mathrm{CN} 44^{\mathrm{T}}$ and $\mathrm{CN} 47^{\mathrm{T}}$ were isolated from a sediment sample taken from the East China Sea $\left(120^{\circ} 34^{\prime}\right.$ E $27^{\circ} 19^{\prime}$ $\mathrm{N})$ by dilution plating on modified ZoBell medium (ZoBell, 1941; Huo et al., 2008) at $37{ }^{\circ} \mathrm{C}$ for 3 days. The isolates were routinely cultured and maintained on Marine 2216 agar (MA, Difco) or broth (MB) or yeast extract broth (YEB, basal medium supplemented with $5 \mathrm{~g}$ yeast extract $1^{-1}$ ) medium (Mikhailov et al., 2006). Basal medium (BM) contained [(1 distilled water $\left.)^{-1}\right]: 1.0 \mathrm{~g}$ $\mathrm{NH}_{4} \mathrm{Cl}, 0.044 \mathrm{~g} \mathrm{~K}_{2} \mathrm{HPO}_{4}, 0.028 \mathrm{~g} \mathrm{FeSO}_{4} .7 \mathrm{H}_{2} \mathrm{O}, 500 \mathrm{ml}$

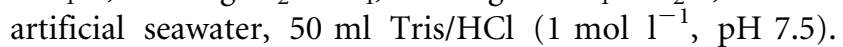
Artificial seawater contained [1 distilled water $)^{-1}$ ]: $23.4 \mathrm{~g}$ $\mathrm{NaCl}, 24.6 \mathrm{~g} \mathrm{MgSO}_{4}$. $7 \mathrm{H}_{2} \mathrm{O}, 1.5 \mathrm{~g} \mathrm{KCl}, 2.9 \mathrm{~g} \mathrm{CaCl}_{2}$.

Growth at various $\mathrm{NaCl}$ concentrations $(0.0,0.5,1.0,3.0$, $5.0,7.5,10.0,12.5$ and $15.0 \%, \mathrm{w} / \mathrm{v})$ was investigated in trypticase soy yeast extract medium (DSMZ medium 92) and YEB medium. The $\mathrm{pH}$ range for growth was determined by adding MES ( $\mathrm{pH}$ 5.0-6.0), PIPES 
( $\mathrm{pH}$ 6.5-7.0), Tricine (pH 7.5-8.5), CAPSO ( $\mathrm{pH}$ 9.0-9.5) and CAPS ( $\mathrm{pH} 10.0-10.5)$ to YEB medium at a concentration of $40 \mathrm{mmol}^{-1}$. The temperature range for growth was determined by incubating at $4,10,15,20,25,30,35$, 40, 42, 45 and $48{ }^{\circ} \mathrm{C}$. Cell morphology and motility were examined by optical microscopy (BX40, Olympus) and transmission electron microscopy (JEM-1230, JEOL).

Single carbon source assimilation tests were performed by using BM. The corresponding filter-sterilized sugar, alcohol, organic acid or amino acid $(0.2 \%)$ was added to liquid medium. Acid production was tested by using modified MOF medium supplemented with $1.0 \%$ sugars or alcohols (Leifson, 1963; Xu et al., 2008). Biochemical and nutritional tests were performed in $\mathrm{MB}$ according to $\mathrm{Xu}$ et al. (2007) as described by Mata et al. (2002). API ZYM and API 20NE (bioMérieux) tests were also used to determine physiological and biochemical characteristics. API ZYM strips were read after $8 \mathrm{~h}$ and API 20NE strips after 24 and $48 \mathrm{~h}$.

Fatty acid methyl esters were prepared from lipids that had been extracted from cells grown on $\mathrm{MB}$ for $36 \mathrm{~h}$ at $30{ }^{\circ} \mathrm{C}$ and analysed by using GC/MS (Kuykendall et al., 1988). Isoprenoid quinones were extracted from freeze-dried cells (200 mg) with chloroform/methanol $(2: 1)$ and analysed by reversed-phase HPLC. Genomic DNA G $+\mathrm{C}$ content was determined by thermal denaturation $\left(T_{\mathrm{m}}\right)$ (Marmur \& Doty, 1962) using Escherichia coli K-12 DNA as the calibration standard.

The 16S rRNA gene was amplified and analysed as described previously (Xu et al., 2007). PCR products were cloned into vector pMD 19-T (TaKaRa) and then sequenced to determine the almost-complete sequence of the 16S rRNA gene. The sequence was compared with closely related sequences of reference organisms from the FASTA and EzTaxon services (Chun et al., 2007). Sequence data were aligned with CLUSTAL W 1.8 (Thompson et al., 1994). Phylogenetic trees were constructed by the neighbour-joining (Saitou \& Nei, 1987) and maximum-parsimony (Fitch, 1971) methods with the MEGA 3 program package (Kumar et al., 2004) and by the maximumlikelihood method (Felsenstein, 1981) with the TREEPUZZLE 5.2 program. Evolutionary distances were calculated according to the algorithm of the Kimura two-parameter model (Kimura, 1980) for the neighbour-joining method.

The two isolates were Gram-negative, rod-shaped, motile, oxidase-positive and possessed Q-8 as predominant quinone. Cells of the strains often contained granules (Fig. 1). Strain $\mathrm{CN} 44^{\mathrm{T}}$ was able to form phase-refractive vesicles inside the cells, whereas strain $\mathrm{CN} 47^{\mathrm{T}}$ was not. Colonies of strain $\mathrm{CN} 44^{\mathrm{T}}$ were yellow-coloured after 2 days incubation on $\mathrm{MA}$; strain $\mathrm{CN} 47^{\mathrm{T}}$ colonies were creamcoloured. Major fatty acids of the two strains were $\mathrm{C}_{18: 1} \omega 7 c, \mathrm{C}_{16: 0}$, iso- $\mathrm{C}_{15: 0} 2-\mathrm{OH}$ and/or $\mathrm{C}_{16: 1} \omega 7 c$ and $\mathrm{C}_{10: 0} 3-\mathrm{OH}$ (Supplementary Table S1, available in IJSEM Online). Other physiological and chemotaxonomic characteristics of strains $\mathrm{CN} 44^{\mathrm{T}}$ and $\mathrm{CN} 47^{\mathrm{T}}$ are summarized in
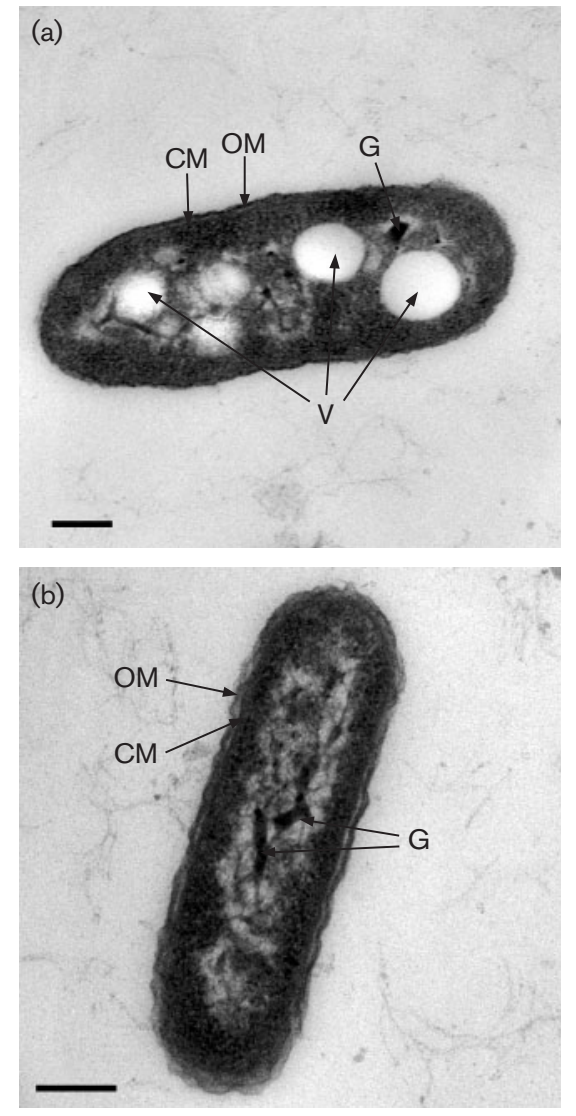

Fig. 1. Transmission electron photographs of ultrathin sections of strains $\mathrm{CN} 44^{\top}$ (a) and $\mathrm{CN} 47^{\top}$ (b). CM, Cytoplasmic membrane; G, intracellular granules; OM, outer membrane; $\mathrm{V}$, vesicles. Bars, $0.2 \mu \mathrm{m}$.

the species descriptions. Phenotypic characteristics that serve to differentiate the two strains from their closest phylogenetic relatives are listed in Table 1.

The almost-complete 16S rRNA gene sequences of strains $\mathrm{CN} 44^{\mathrm{T}}$ (1463 nt) and $\mathrm{CN}^{2} 7^{\mathrm{T}}$ (1464 nt) were obtained. Sequence comparisons to representative bacteria with validly published names indicated that strain $\mathrm{CN} 44^{\mathrm{T}}$ was related most closely to the genus Marinobacterium (91.9$95.3 \%$ sequence similarity). Phylogenetic analysis based on $16 \mathrm{~S}$ rRNA gene sequences showed that the isolate formed a coherent cluster with M. rhizophilum (Fig. 2). The topologies of the phylogenetic trees that were built by using the maximum-likelihood and maximum-parsimony algorithms also supported the notion that strain $\mathrm{CN} 44^{\mathrm{T}}$ could represent a species phylogenetically distinct from closely related species in the genus Marinobacterium. Strain $\mathrm{CN} 47^{\mathrm{T}}$ showed the highest sequence similarity to $M$. stanieri $(97.8 \%)$ and $<97 \%$ sequence similarity to other described Marinobacterium species. Phylogenetic analysis based on the 16S rRNA gene sequence showed that strain $\mathrm{CN} 47^{\mathrm{T}}$ formed a coherent cluster with $M$. stanieri with a high bootstrap-resampling value $(99 \%$ by the neighbourjoining method) (Fig. 2). 
Table 1. Differential phenotypic characteristics of the isolates and other related Marinobacterium species

Taxa: 1, CN44 ${ }^{\mathrm{T}}$; 2, CN47 ${ }^{\mathrm{T}}$; 3, M. stanieri DSM 7027 ${ }^{\mathrm{T}}$; 4, M. rhizophilum (data from Kim et al., 2008); 5, M. georgiense (González et al., 1997); 6, M. halophilum (Chang et al., 2007); 7, M. litorale (Kim et al., 2007); 8, M. jannaschii (Bowditch et al., 1984). +, Positive; -, negative; (+) and (-), positive or negative results reported for half or more strains of the species; w, weak; ND, no data available. All strains are motile, rod-shaped and oxidase-positive and possess Q-8 as predominant quinone.

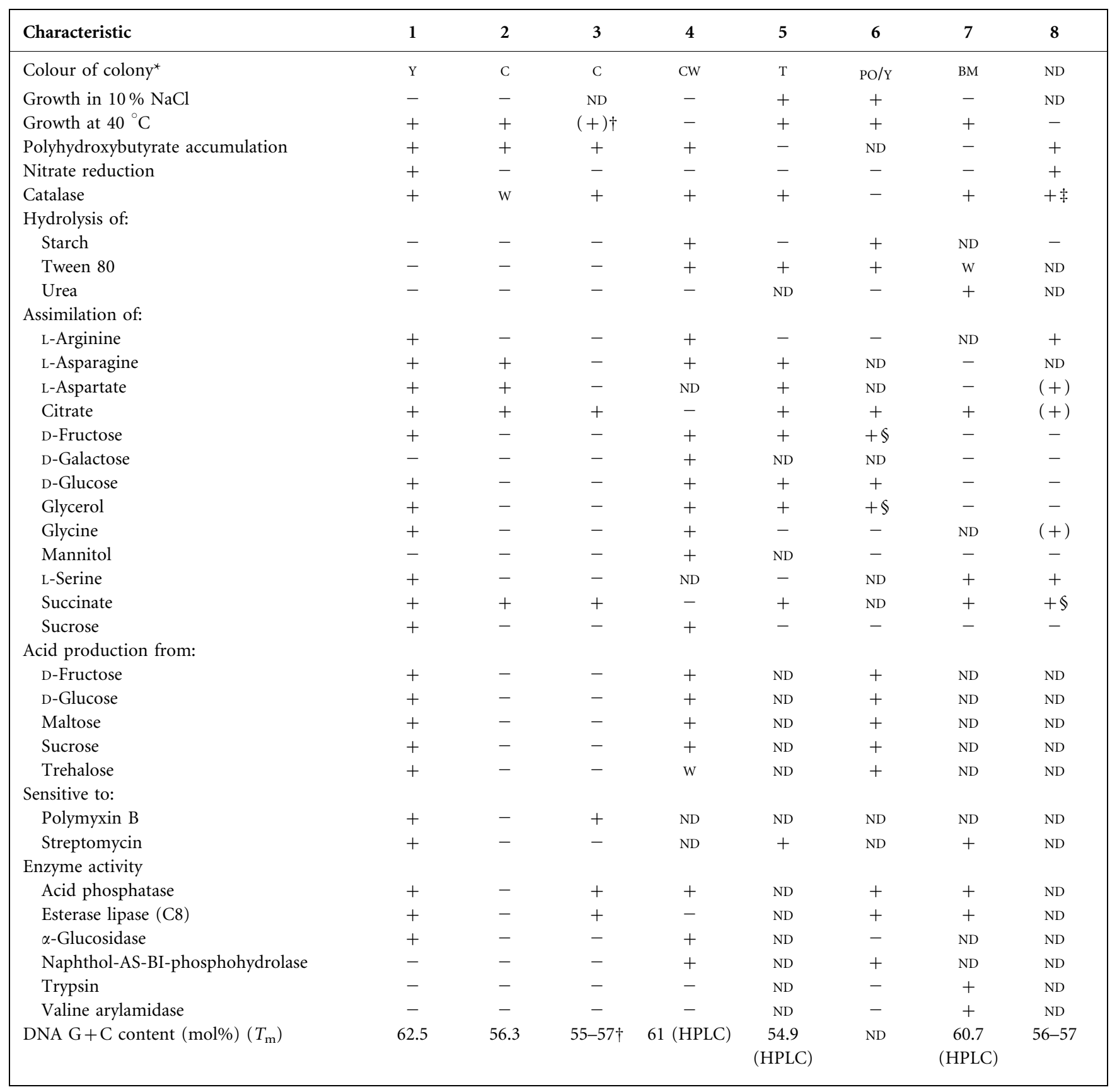

${ }^{*}$ BM, Beige-milky; C, cream; CW, creamy white; PO, pale orange; T, translucent; Y, yellow.

$\dagger$ Data from Baumann et al. (1983).

\$Data from Satomi et al. (2002).

§Data from Kim et al. (2007). 


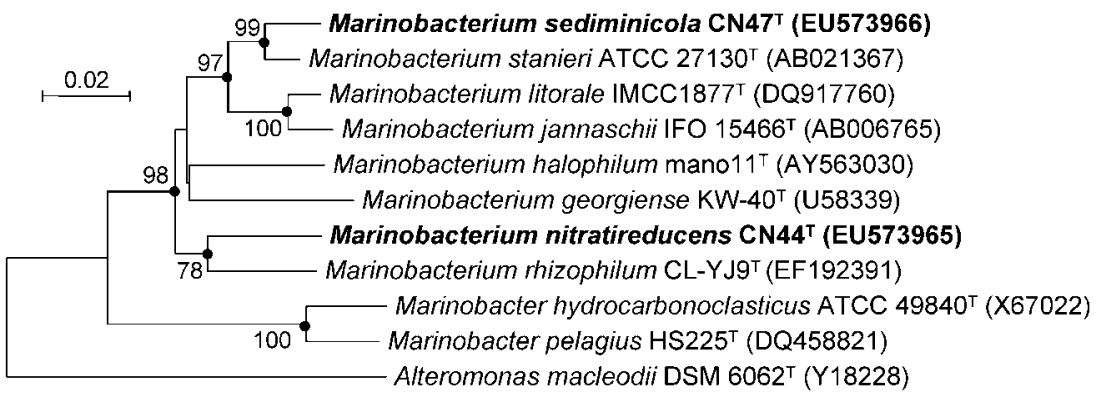

Fig. 2. Neighbour-joining tree based on $16 \mathrm{~S}$ rRNA gene sequences, showing the phylogenetic relationships of the novel isolates and related taxa. Bootstrap values are based on 1000 replicates; values $>70 \%$ are shown. indicates nodes that were recovered with bootstrap values $>60 \%$ in both maximumlikelihood and maximum-parsimony trees. Bar, 0.02 substitutions per nucleotide position.

To verify the species status of the novel Marinobacterium species, DNA-DNA hybridizations were performed by the thermal denaturation and renaturation method of De Ley et al. (1970) as modified by $\operatorname{Hu} \beta$ et al. (1983), using a Beckman DU 800 spectrophotometer. The DNA-DNA relatedness value of strain $\mathrm{CN} 47^{\mathrm{T}}$ to $M$. stanieri DSM $7027^{\mathrm{T}}$ was $46 \%$. The $16 \mathrm{~S}$ rRNA gene sequence similarity values, as well as DNA relatedness value, were sufficiently low to classify strains $\mathrm{CN} 44^{\mathrm{T}}$ and $\mathrm{CN} 47^{\mathrm{T}}$ as representatives of two novel species within the genus Marinobacterium.

Based on the phenotypic differentiation (Table 1) and genotypic data presented above, we consider that strains $\mathrm{CN} 44^{\mathrm{T}}$ and $\mathrm{CN} 47^{\mathrm{T}}$ represent two novel species of the genus Marinobacterium, for which the names Marinobacterium nitratireducens sp. nov. and Marinobacterium sediminicola sp. nov., respectively, are proposed.

\section{Description of Marinobacterium nitratireducens sp. nov.}

Marinobacterium nitratireducens (ni.tra.ti.re.du'cens. N.L. n. nitras -atis nitrate; L. part. adj. reducens converting to a different state; N.L. adj. nitratireducens reducing nitrate).

Cells are Gram-negative and motile. Young cultures show rod-like cells $(1.0-3.0 \times 0.5-0.8 \mu \mathrm{m})$. Colonies on MA are $1-2 \mathrm{~mm}$ in diameter, circular, smooth, elevated and yellow-coloured after 2 days at $30{ }^{\circ} \mathrm{C}$. No growth occurs in the absence of salt. Growth occurs at $\mathrm{NaCl}$ concentrations of $0.5-7.5 \%(\mathrm{w} / \mathrm{v})$, with optimum growth at 1.0 $3.0 \%$. The $\mathrm{pH}$ and temperature ranges for growth are $\mathrm{pH}$ 5.5-9.5 and $15-40{ }^{\circ} \mathrm{C}$ (optimum growth at $\mathrm{pH} 7.0-8.0$ and $35^{\circ} \mathrm{C}$ ). Oxidase- and catalase-positive. Tyrosine is hydrolysed. Aesculin, casein, DNA, gelatin, starch and Tweens 20 and 80 are not hydrolysed. Nitrate is reduced. Arginine dihydrolase, $\beta$-galactosidase, gluconate oxidation, indole production, lecithinase, lysine and ornithine carboxylases and urease activities are negative. $\mathrm{H}_{2} \mathrm{~S}$ is not produced from thiosulfate. The following substrates are utilized for growth: acetate, L-alanine, L-arginine, asparagine, L-aspartate, citrate, ethanol, D-fructose, gluconate, D-glucose, glutamate, L-glutamine, glycerol, glycine, Lisoleucine, lactate, L-lysine, malate, malonate, maltose, myo-inositol, propionate, pyruvate, L-serine, sorbitol, succinate, sucrose, trehalose and L-valine. The following compounds are not utilized as sole carbon sources:
$\mathrm{N}$-acetylglucosamine, adonitol, L-arabinose, D-cellobiose, L-cysteine, formate, fumarate, D-galactose, L-histidine, lactose, mannitol, D-mannose, L-methionine, raffinose, Lrhamnose, D-ribose, L-sorbose and D-xylose. Acid is produced from D-fructose, D-glucose, maltose, myoinositol, sucrose and trehalose. Susceptible to ( $\mu$ g unless otherwise stated): amoxicillin (10), ampicillin (10), carbenicillin (100), cefataxime (30), cefoxitin (30), ceftriaxone (30), chloramphenicol (30), erythromycin (15), kanamycin (30), neomycin (30), nitrofurantoin (300), penicillin (10), polymyxin B (300 IU), rifampicin (5), streptomycin (10), tobramycin (10) and tetracycline (30), but not to bacitracin (0.04 IU), novobiocin (30) or nystatin (100). In the API ZYM system, acid and alkaline phosphatases, esterase (C4), esterase lipase (C8), $\alpha$-glucosidase and leucine arylamidase activities are present, whereas $N$-acetyl- $\beta$-glucosaminidase, $\alpha$-chymotrypsin, cystine arylamidase, $\alpha$-fucosidase, $\alpha$ - and $\beta$-galactosidases, $\beta$-glucosidase, $\beta$-glucuronidase, lipase (C14), $\alpha$-mannosidase, naphthol-AS-BI-phosphohydrolase, trypsin and valine arylamidase activities are absent. Ubiquinone- 8 is the major respiratory quinone. Major fatty acids $(>5 \%)$ are $\mathrm{C}_{18: 1} \omega 7 c, \mathrm{C}_{16: 0}$, iso- $\mathrm{C}_{15: 0} 2-\mathrm{OH}$ and/or $\mathrm{C}_{16: 1} \omega 7 c$ and $\mathrm{C}_{10: 0} 3-\mathrm{OH}$. The DNA G $+\mathrm{C}$ content of the type strain is $62.5 \mathrm{~mol} \%\left(T_{\mathrm{m}}\right)$.

The type strain, $\mathrm{CN} 44^{\mathrm{T}}$ (=CGMCC $1.7286^{\mathrm{T}}=\mathrm{JCM}$ $15523^{\mathrm{T}}$ ), was isolated from a marine sediment sample of Zhejiang, China.

\section{Description of Marinobacterium sediminicola sp. nov.}

Marinobacterium sediminicola (se.di.mi.ni'co.la. L. n. sedimen -inis sediment; L. suff. -cola inhabitant, dweller; N.L. n. sediminicola sediment dweller).

Cells are Gram-negative and motile. Young cultures show rod-like cells $(1.0-2.0 \times 0.3-0.5 \mu \mathrm{m})$. Colonies on MA are $1 \mathrm{~mm}$ in diameter, circular, smooth, elevated and creamcoloured after 2 days at $30{ }^{\circ} \mathrm{C}$. No growth occurs in the absence of salt. Growth occurs at $\mathrm{NaCl}$ concentrations of $0.5-7.5 \%(\mathrm{w} / \mathrm{v})$, with optimum growth at $1.0-3.0 \%$. The $\mathrm{pH}$ and temperature ranges for growth are $\mathrm{pH} 6.0-9.5$ and $15-42{ }^{\circ} \mathrm{C}$ (optimum growth at $\mathrm{pH} 7.0$ and $35^{\circ} \mathrm{C}$ ). Oxidase- and catalase-positive. Tween 20 and tyrosine are hydrolysed. Aesculin, casein, DNA, gelatin, starch and Tween 80 are not hydrolysed. Nitrate is not reduced. 
Arginine dihydrolase, $\beta$-galactosidase, gluconate oxidation, indole production, lecithinase, lysine and ornithine carboxylases and urease are negative. $\mathrm{H}_{2} \mathrm{~S}$ is not produced from thiosulfate. The following substrates are utilized for growth: acetate, L-alanine, asparagine, L-aspartate, citrate, ethanol, glutamate, L-glutamine, L-isoleucine, lactate, malate, propionate, pyruvate, succinate and L-valine. The following compounds are not utilized as sole carbon sources: $\mathrm{N}$-acetylglucosamine, adonitol, L-arabinose, Larginine, D-cellobiose, L-cysteine, formate, D-fructose, fumarate, D-galactose, gluconate, D-glucose, glycerol, glycine, L-histidine, lactose, L-lysine, malonate, maltose, mannitol, D-mannose, L-methionine, myo-inositol, raffinose, L-rhamnose, D-ribose, L-serine, sorbitol, L-sorbose, sucrose, trehalose and D-xylose. Susceptible to ( $\mu \mathrm{g}$ unless otherwise stated): amoxicillin (10), ampicillin (10), carbenicillin (100), cefataxime (30), cefoxitin (30), ceftriaxone (30), chloramphenicol (30), erythromycin (15), kanamycin (30), neomycin (30), nitrofurantoin (300), novobiocin (30), penicillin (10), rifampicin (5), tobramycin (10) and tetracycline (30), but not to bacitracin (0.04 IU), nystatin (100), polymyxin B (300 IU) or streptomycin (10). In the API ZYM system, alkaline phosphatase, esterase (C4) and leucine arylamidase activities are present, whereas acid phosphatase, $N$-acetyl- $\beta$-glucosaminidase, $\alpha$-chymotrypsin, cystine arylamidase, esterase lipase (C8), $\alpha$-fucosidase, $\alpha$ and $\beta$-galactosidases, $\alpha$ - and $\beta$-glucosidases, $\beta$-glucuronidase, lipase (C14), $\alpha$-mannosidase, naphthol-AS-BI-phosphohydrolase, trypsin and valine arylamidase activities are absent. Ubiquinone- 8 is the major respiratory quinone. Major fatty acids $(>5 \%)$ are $\mathrm{C}_{18: 1} \omega 7 c, \mathrm{C}_{16: 0}$, iso- $\mathrm{C}_{15: 0} 2$ $\mathrm{OH}$ and/or $\mathrm{C}_{16: 1} \omega 7 c$ and $\mathrm{C}_{10: 0} 3-\mathrm{OH}$. The DNA G+C content of the type strain is $56.3 \mathrm{~mol} \%\left(T_{\mathrm{m}}\right)$.

The type strain, $\mathrm{CN} 47^{\mathrm{T}} \quad\left(=\mathrm{CGMCC} \quad 1.7287^{\mathrm{T}}=\mathrm{JCM}\right.$ $15524^{\mathrm{T}}$ ), was isolated from a marine sediment sample of Zhejiang, China.

\section{Acknowledgements}

We thank Jean Euzéby for his help with the specific etymology and nomenclature. This work was supported by grants from the Major State Basic Research Development Program of China (973 Program) (2004CB719604-3), the Scientific Research Fund of the Second Institute of Oceanography, SOA (JT0709), the National High Technology Research and Development Program of China (863 Program) (2007AA021305), the Chinese Offshore Investigation and Assessment (908-ZC-I-02) and the National Infrastructure of Natural Resources for Science and Technology (2005DKA21206).

\section{References}

Baumann, P., Bowditch, R. D., Baumann, L. \& Beaman, B. (1983). Taxonomy of marine Pseudomonas species: P. stanieri sp. nov.; $P$. perfectomarina sp. nov., nom. rev.; P. nautica; and P. doudoroffii. Int $J$ Syst Bacteriol 33, 857-865.

Bowditch, R. D., Baumann, L. \& Baumann, P. (1984). Description of Oceanospirillum kriegii sp. nov. and O. jannaschii sp. nov. and assignment of two species of Alteromonas to this genus as O. commune comb. nov. and O. vagum comb. nov. Curr Microbiol 10, 221-230.
Chang, H.-W., Nam, Y.-D., Kwon, H.-Y., Park, J. R., Lee, J.-S., Yoon, J.-H., An, K.-G. \& Bae, J.-W. (2007). Marinobacterium halophilum sp. nov., a marine bacterium isolated from the Yellow Sea. Int J Syst Evol Microbiol 57, 77-80.

Chun, J., Lee, J. H., Jung, Y., Kim, M., Kim, S., Kim, B. K. \& Lim, Y. W. (2007). EzTaxon: a web-based tool for the identification of prokaryotes based on 16S ribosomal RNA gene sequences. Int J Syst Evol Microbiol 57, 2259-2261.

De Ley, J., Cattoir, H. \& Reynaerts, A. (1970). The quantitative measurement of DNA hybridization from renaturation rates. Eur $J$ Biochem 12, 133-142.

Euzéby, J. P. \& Tindall, B. J. (2004). Status of strains that contravene Rules 27(3) and 30 of the Bacteriological Code. Request for an opinion. Int J Syst Evol Microbiol 54, 293-301.

Felsenstein, J. (1981). Evolutionary trees from DNA sequences: a maximum likelihood approach. J Mol Evol 17, 368-376.

Fitch, W. M. (1971). Toward defining the course of evolution: minimum change for a specific tree topology. Syst Zool 20, 406416.

González, J. M., Mayer, F., Moran, M. A., Hodson, R. E. \& Whitman, W. B. (1997). Microbulbifer hydrolyticus gen. nov., sp. nov., and Marinobacterium georgiense gen. nov., sp. nov., two marine bacteria from a lignin-rich pulp mill waste enrichment community. Int J Syst Bacteriol 47, 369-376.

Huo, Y.-Y., Wang, C.-S., Yang, J.-Y., Wu, M. \& Xu, X.-W. (2008). Marinobacter mobilis sp. nov. and Marinobacter zhejiangensis sp. nov., halophilic bacteria isolated from the East China Sea. Int J Syst Evol Microbiol 58, 2885-2889.

Hu/, V. A. R., Festl, H. \& Schleifer, K. H. (1983). Studies on the spectrophotometric determination of DNA hybridization from renaturation rates. Syst Appl Microbiol 4, 184-192.

Kim, H., Choo, Y.-J., Song, J., Lee, J.-S., Lee, K. C. \& Cho, J.-C. (2007). Marinobacterium litorale sp. nov. in the order Oceanospirillales. Int J Syst Evol Microbiol 57, 1659-1662.

Kim, Y.-G., Jin, Y.-A., Hwang, C. Y. \& Cho, B. C. (2008). Marinobacterium rhizophilum sp. nov., isolated from the rhizosphere of the coastal tidal-flat plant Suaeda japonica. Int J Syst Evol Microbiol 58, 164-167.

Kimura, M. (1980). A simple method for estimating evolutionary rates of base substitutions through comparative studies of nucleotide sequences. J Mol Evol 16, 111-120.

Kumar, S., Tamura, K. \& Nei, M. (2004). MEGA3: integrated software for molecular evolutionary genetics analysis and sequence alignment. Brief Bioinform 5, 150-163.

Kuykendall, L. D., Roy, M. A., O’Neill, J. J. \& Devine, T. E. (1988). Fatty acids, antibiotic resistance, and deoxyribonucleic acid homology groups of Bradyrhizobium japonicum. Int J Syst Bacteriol 38, 358-361.

Leifson, E. (1963). Determination of carbohydrate metabolism of marine bacteria. J Bacteriol 85, 1183-1184.

Marmur, J. \& Doty, P. (1962). Determination of the base composition of deoxyribonucleic acid from its thermal denaturation temperature. J Mol Biol 5, 109-118.

Mata, J. A., Martínez-Cánovas, J., Quesada, E. \& Béjar, V. (2002). A detailed phenotypic characterisation of the type strains of Halomonas species. Syst Appl Microbiol 25, 360-375.

Mikhailov, V. V., Romanenko, L. A. \& Ivanova, E. P. (2006). The genus Alteromonas and related proteobacteria. In The Prokaryotes: a Handbook on the Biology of Bacteria, 3rd edn, vol. 6, pp. 597-645. Edited by M. Dworkin, S. Falkow, E. Rosenberg, K. H. Schleifer \& E. Stackebrandt. New York: Springer. 
Saitou, N. \& Nei, M. (1987). The neighbor-joining method: a new method for reconstructing phylogenetic trees. Mol Biol Evol 4, 406-425.

Satomi, M., Kimura, B., Hamada, T., Harayama, S. \& Fujii, T. (2002). Phylogenetic study of the genus Oceanospirillum based on 16S rRNA and gyrB genes: emended description of the genus Oceanospirillum, description of Pseudospirillum gen. nov., Oceanobacter gen. nov. and Terasakiella gen. nov. and transfer of Oceanospirillum jannaschii and Pseudomonas stanieri to Marinobacterium as Marinobacterium jannaschii comb. nov. and Marinobacterium stanieri comb. nov. Int J Syst Evol Microbiol 52, 739-747.

Thompson, J. D., Higgins, D. G. \& Gibson, T. J. (1994). CluSTAL W: improving the sensitivity of progressive multiple sequence alignment through sequence weighting, position-specific gap penalties and weight matrix choice. Nucleic Acids Res 22, 4673-4680.

Xu, X.-W., Wu, Y.-H., Zhou, Z., Wang, C.-S., Zhou, Y.-G., Zhang, H.-B., Wang, Y. \& Wu, M. (2007). Halomonas saccharevitans sp. nov., Halomonas arcis sp. nov. and Halomonas subterranea sp. nov., halophilic bacteria isolated from hypersaline environments of China. Int J Syst Evol Microbiol 57, 1619-1624.

Xu, X.-W., Wu, Y.-H., Wang, C.-S., Yang, J.-Y., Oren, A. \& Wu, M. (2008). Marinobacter pelagius sp. nov., a moderately halophilic bacterium. Int J Syst Evol Microbiol 58, 637-640.

ZoBell, C. E. (1941). Studies on marine bacteria. I. The cultural requirements of heterotrophic aerobes. J Mar Res 4, 42-75. 